\title{
Is Hyperflexion Possible with the Solitary Use of High- Flexion Insert in Knee Replacement Preserving the Posterior Cruciate Ligament? (Mid-term Results)
}

\author{
Arka Çapraz Bağı Koruyan Diz Protezinde Sadece Hiperfleksiyona \\ İzin Veren Ara Yüzeyin Kullanımı Hiperfleksiyon Sağlıyor mu? (Orta \\ Dönem Sonuçlar)
}

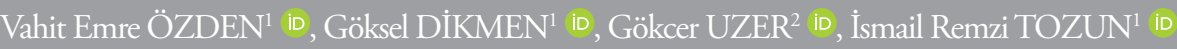 \\ ${ }^{1}$ Department of Orthopedics and Traumatology, Acibadem University School of Medicine, İstanbul, Turkey \\ ${ }^{2}$ Department of Orthopedics and Traumatology, Bezmialem Vakif University School of Medicine, İstanbul, Turkey}

\section{ABSTRACT}

Objective: For evaluating the early midterm results of our patients who underwent total knee replacement allowing for hyperflexion and for identifying the factors affecting the range of flexion in particular.

Methods: A total of 150 knees of 95 patients who underwent total knee replacement using a high-flexion cruciate retaining insert were evaluated. The patients were followed up for a mean of 8.5 (3.5-11) years. The knee joints were assessed pre- and postoperatively and at the final follow-up using the Knee Society Scoring System and their ranges of motion were recorded. The component survival was also investigated.

Results: The mean preoperative knee score was $49.1 \pm 12.0$, the mean functional score was $48.9 \pm 14.1$ and the mean range of flexion was $119.3 \pm 18.9$ degrees. The same values of the follow-up improved on $92.9 \pm 8.2(p<0.0001), 90.7 \pm 10.6(p<0.0001)$ and $128.0 \pm 11.5$ degrees $(p<0.0001)$, respectively. A moderate correlation was detected between the preoperative and postoperative ranges of flexion $(r=0.623, p<0.0001)$. There was an insert revision of one knee $(0.6 \%)$ because of early infection. No revision was required owing to aseptic loosening. Analysis using the ROC revealed the probability of postoperative hyperflexion of $130^{\circ}$ and above in knees that had a preoperative range of flexion of $115^{\circ}$ and above.

Conclusion: The postoperative range of flexion was found to correlate with the preoperative range of flexion. The results of our study showed that a higher range of flexion is not possible with the solitary use of high-flex Cruciate Retaining insert and the preoperative range of flexion is an important factor in attaining hyperflexion even with the use of such inserts.

Keywords: Cruciate retaining, knee replacement, hyper-flex knee

\section{öz}

Amaç: Hiperfleksiyona izin veren tasarımlı total diz protezi uyguladığımız hastalarımızın erken-orta dönem sonuçlarını değerlendirmek ve özellikle fleksiyon açıklığı üzerine etkili faktörleri belirlemek.

Yöntemler: Hiperflex arka çapraz bağ koruyan tipi diz protezi uyguladığımız 95 hastanın 150 dizi değerlendirmeye alındı. Hastalar ortalama 8.5 yıl (3.5-11 yil) takip edildiler. Diz eklemleri ameliyat öncesinde ve son kontrolde Diz Cemiyeti Puanlama Sistemi ile değerlendirildi ve hareket açıklıkları kaydedildi. Komponent sağkalımı değerlendirildi. Ameliyat sonrasında yüksek fleksiyon derecesine (>130) ulaşabilmek için ameliyat öncesinde olması gereken fleksiyon açıklığı ise ROC eğrisi (receiver-operating characteristic) analizi ile araştırıldı.

Bulgular: Ameliyat öncesi ortalama diz skoru 49.1 \pm 12.0 puan, fonksiyon skoru $48.9 \pm 14.1$ puan ve fleksiyon açısı 119.3 \pm 18.9 derece olarak bulundu. Son kontrollerde aynı değerler sırasıyla $92.9 \pm 8.2(\mathrm{p}<0.0001), 90.7 \pm 10.6(\mathrm{p}<0.0001)$ ve $128.0 \pm 11.5 \mathrm{de}-$ rece $(\mathrm{p}<0.0001)$ seviyesine yükseldi. Yetmiş $(47 \%)$ dizde fleksiyon açıklığında bir artış sağlanamazken, bu hastalardan 27 'sinde $(18 \%)$ dizde fleksiyon değerinde azalma oldu. Ameliyat öncesi ve sonrası fleksiyon açıklıkları arasında orta seviyede korelasyon tespit edildi $(\mathrm{r}=0.623, \mathrm{p}<0.0001)$. Bir adet $(0.6 \%)$ ara yüzey revizyonu erken dönem enfeksiyon nedeni ile yapıldı. Aseptik gevşeme gözlenmedi. ROC eğrisi analizi ameliyat öncesinde $115^{\circ}$ ve üzerinde fleksiyonu olan dizlerde ameliyat sonrasında $130^{\circ}$ ve üzerinde hiperfleksiyon beklenebileceğini tespit edildi.

Sonuç: Çalışmamızın sonucunda ameliyat sonrası fleksiyon derecesi, ameliyat öncesi fleksiyon derecesi ile ilişkili olarak bulunmuştur. Bu çalışma ile sadece yüksek fleksiyona izin veren ara yüzey kullanarak yüksek fleksiyon dereceleri elde edilemeyeceği, ameliyat öncesi fleksiyon açıklığının hiperfleksiyona ulaşmanın bu tip tasarımda bile önemli bir faktör olduğu sonucuna ulaşıldı.

Anahtar Sözcükler: Bağkoruyan arayüzey, hiperfleksiyon, diz artroplastisi

\section{Introduction}

Total knee arthroplasty (TKA) is a successful and reliable method that recently often been employed for treating arthrosis of the knee (1). The rate of patient satisfaction reaches $80 \%$ and above (2). The increasing mean age of the community

Cite this article as: Özden VE, Dikmen G, Uzer G, Tozun IR. Is Hyperflexion Possible with the Solitary Use of High-Flexion Insert in Knee Replacement Preserving the Posterior Cruciate Ligament? (Mid-term Results) Bezmialem Science 2018; 6(4): 288-93. 
and the successful survival outcomes of TKA in young people have doubled the number of TKA applications for the last 10 years $(3,4)$. Postoperative range of motion is an important determinant of the functional outcomes following TKA (2). Therefore, in an attempt to attain a higher range of motion, new designs with modifications in the femoral component and polyethylene geometry were developed for allowing hyperflexion. However, the benefit of the femoral component designs allowing hyperflexion is debatable (5-7). Studies on increasing the range of motion following TKA and on the modified designs of the polyethylene insert in prostheses substituting or retaining the posterior cruciate ligament (PCL) are limited in the literature (8-10). The range of motion has been shown to increase with the modification of the polyethylene insert in PS (PCL-substituting) prostheses (8), whereas no clinical difference was found in a randomized controlled study (9). The advantages of modifications in the design of the high-flexion CR (Cruciate Retaining) insert have also been shown (10).

In the present study, we aimed to evaluate the early midterm results of our patients who underwent PCL-preserving TKA with the high-flexion insert in our clinic and the relationship between the pre- and postoperative ranges of motion.

\section{Methods}

A total of 162 knees of 103 patients underwent a PCLpreserving TKA using only high-flexion inserts (Genesis II; Smith \& Nephew, Memphis, TN, USA), performed by a single senior surgeon between 2006 and 2014. One hundred and fifty knees of 95 patients (88 females, 7 males) were included in this study. Eight patients were lost to follow-up. The study protocol was performed in compliance with the principles of the World Medical Association Declaration of Helsinki "Ethical Principles for Medical Research Involving Human Subjects" (amended in October 2013). The mean age of the patients was $71(22-85)$ years. The patients had a mean weight of 78 (64-104) $\mathrm{kg}$ and a mean height of 157 $(145-168) \mathrm{cm}$. Four patients (seven knees) were diagnosed with rheumatoid arthritis, two patients (two knees) with systemic lupus erythematosus, three patients (three knees) with posttraumatic arthritis, and others with primary osteoarthritis. Bilateral TKA was performed on 71 patients during the same session and on four patients in successive sessions. Ten patients of the bilateral TKA group had a PS-type prosthesis on their contralateral side. Of them, only those with a CR prosthesis were included in the study. The mean follow-up period was $8.1(3,5-11)$ years.

Pre- and postoperative ranges of motion of the knees were recorded using the neutral zero methods and the patients were evaluated using the Knee Society Scoring System (4). Progressive radiolucency between the bone and the components and loosening or migration of the implant were evaluated after observation in the follow-up radiographs (anteroposteriorlateral and patella tangential views).

\section{Surgical Technique}

All patients were administered a combination of spinal-epidural anesthesia and the epidural catheter was left in place for 48 hours after surgery for patient-controlled analgesia. Antibiotic prophylaxis was initiated with IV injection of $2 \mathrm{~g}$ of cefazolin half an hour before skin incision and was continued for 48 hours with IV injections of $1 \mathrm{~g}$ every 6 hours. No tourniquet was used during the surgeries. Following the anterior longitudinal cutaneous-subcutaneous incision, the joint was exposed with medial parapatellar arthrotomy. Bone incisions were performed with incision guides after necessary soft tissue releases. Intramedullary guides were used on the femoral side and extramedullary guides were used on the tibial side in all cases. As the type of the high-flexion tibial polyethylene insert was the PCL-retaining type, the PCL was preserved in all cases. Cemented femoral and tibial components were used in all cases. Cemented, polyethylene biconvex patellar component was used in 137 knees. Circumpatellar denervation, osteophyte resection, and "aggressive patelloplasty" were performed on the remaining 13 knees, which we describe as the dome-shaped correction of the patella and its decompression by drilling. The skin was closed and the knee was bandaged. No drains were used.

Low-molecular-weight heparin and thromboembolic prophylaxis were administered in all patients. Prophylaxis was initiated 10-12 hours after epidural catheter application with the subcutaneous injection of $0.4 \mathrm{~mL}$ of enoxaparin and was continued throughout the hospitalization period for a mean of 4.8 (3-7) days. Patients continued receiving the same dose of enoxaparin for a minimum of four weeks.

Rehabilitation was initiated with leg swings over the side of the bed on the day of surgery and mobilization in the room approximately 6-18 hours following surgery. A continuous passive motion device was used for flexing the knee for $30^{\circ}$ $60^{\circ}$ on the day of surgery and the exercises continued for a mean of 4.8 (3-7) days throughout the hospitalization period, 2-3 sessions a day and for 2 hours per session. The range of flexion was increased from $30^{\circ}$ to $40^{\circ}$ each day, depending on the tolerability of the patient.

\section{Statistical Analysis}

The mean pre- and postoperative values were compared using paired, two-sample Student $t$ test. The effects of age, preoperative knee scores, and ranges from motion on the range of flexion were analyzed using correlation tests. In cases where the sampling size was low as in the patellar surface replacement group, the Mann-Whitney U Test was used for comparisons. The receiver operating characteristic (ROC) curve analysis was used for investigating the required preoperative range of flexion to achieve a high postoperative range of flexion $\left(>130^{\circ}\right)$. The value of the identified level was measured using Fisher's exact $\times 2$ test. Statistical Package for Social Sciences version 21 (IBM SPSS Corp.; Armonk, NY, USA) statistical software was used for statistical evaluation. The statistical significance level was set at $\mathrm{p}<0.05$. 
Table 1. The mean pre- and postoperative flexion degrees $\left({ }^{\circ}\right)$ and Knee Society (Knee and Function) scores

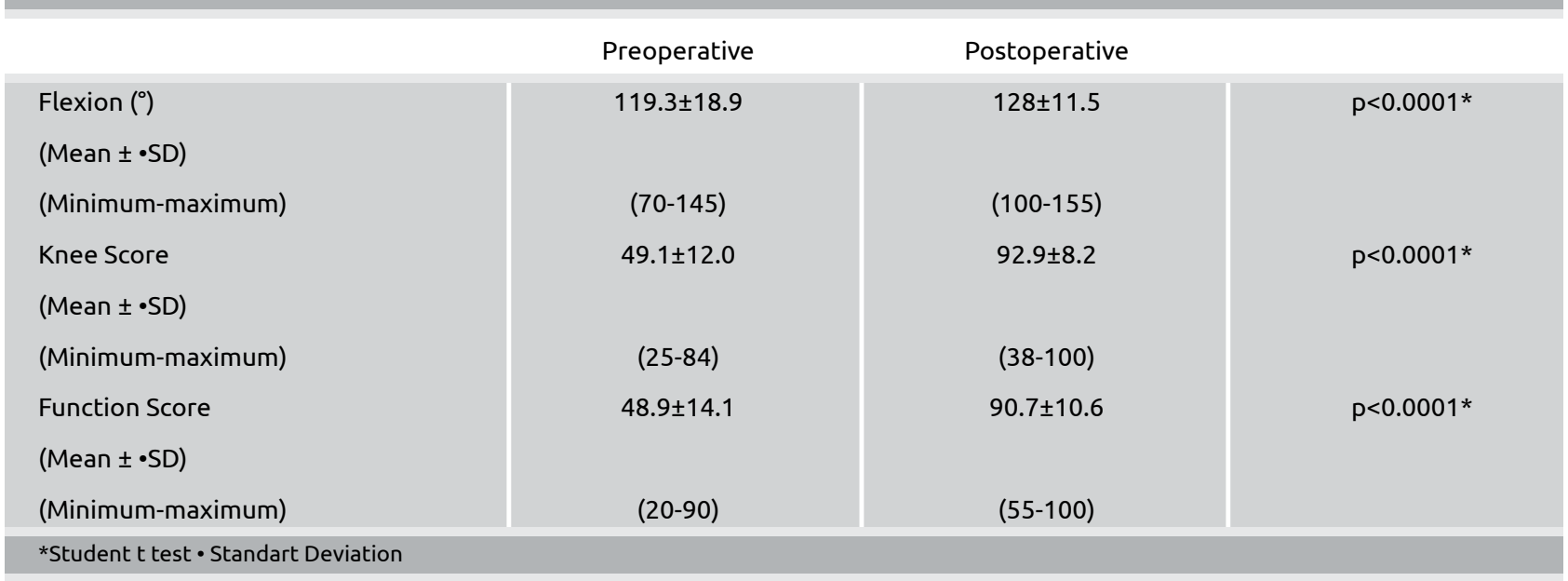

Table 2. Comparison of mean preoperative flexion degrees of the knees that achieved hyperflexion $\left(\geq 130^{\circ}\right)$ and those did not

\begin{tabular}{|c|c|c|}
\hline $\begin{array}{l}\text { Postoperative } \\
\text { Flexion (。) }\end{array}$ & Knee (n) & $\begin{array}{c}\text { Mean Preoperative } \\
\text { Flexion }\left({ }^{\circ}\right)\end{array}$ \\
\hline$<130$ & 60 & $106 \pm 17$ \\
\hline$\geq 130$ & 90 & $128 \pm 14$ \\
\hline
\end{tabular}

Table 3. Comparison of knees that had preoperative range of flexion of $115^{\circ}$ and above with below degrees that reached postoperative hyperflexion $\left(\geq 130^{\circ}\right)$

\begin{tabular}{|c|c|c|c|c|}
\hline & & $\begin{array}{r}\text { Post } \\
\text { Hiperfl }\end{array}$ & $\begin{array}{l}\text { ative } \\
\mathrm{n} \geq 130 \text {. }\end{array}$ & \\
\hline & & - & + & Total \\
\hline Рreoperative flexion $\geq 115^{\bullet}$ & - & 43 & 16 & 59 \\
\hline & + & 17 & 74 & 91 \\
\hline Total & 60 & 90 & 150 & \\
\hline
\end{tabular}

Fischer's Exact test, $p<0.001$

\section{Results}

The mean knee score was $49.1 \pm 12.0$ (25-84) preoperatively and $92.9 \pm 8.2(38-100)$ at the final follow-up $(\mathrm{p}<0.0001)$. The mean functional score also improved on the preoperative value from 48.9 $\pm 14.1(20-90)$ to $90.7 \pm 10.6(55-100)$ postoperatively $(\mathrm{p}<0.0001)$. The mean preoperative flexion of $119.3^{\circ} \pm 18.9^{\circ}\left(70^{\circ}\right.$ $\left.145^{\circ}\right)$ showed a significant increase and reached $128.0^{\circ} \pm 11.5^{\circ}$ $\left(100^{\circ}-155^{\circ}\right)$ following surgery $(\mathrm{p}<0.0001)$ (Table 1$)$. The mean increase in flexion was $8.6^{\circ} \pm 15.9^{\circ}\left(-35^{\circ}-45^{\circ}\right)$. No increase in the range of flexion was achieved in 70 knees $(47 \%)$ while the number decreased to 27 patients (18\%). The mean range of flexion of the patients (seven knees) diagnosed with rheumatoid arthritis was $127.1^{\circ}\left(110^{\circ}-140^{\circ}\right)$ at the final follow-up.
Anterior knee pain developed in seven (4\%) knees of six patients, one bilaterally, which did not have a significant effect on daily activities. Four of these knees had undergone patellar replacement and aggressive patelloplasty had been performed on the other three. The patellar surface was kept in 13 patients. No significant difference was found between the two groups in terms of age $(\mathrm{p}=0.06)$, the preoperative and postoperative ranges of flexion $(\mathrm{p}=0.88$ and $\mathrm{p}=0.88)$, increase in the range of flexion $(\mathrm{p}=0.86)$, and the preoperative and postoperative knee $(\mathrm{p}=0.21$ and $\mathrm{p}=0.51)$ and functional $(\mathrm{p}=0.82$ and $\mathrm{p}=0.11$ ) scores (Mann-Whitney U Test).

An intraoperative patellar fracture developed in one knee $(0.6 \%)$ and superficial wound site infection was observed in two knees $(1.3 \%)$, which healed with antibiotic treatment. Acute deep periprosthetic infection treated by changing of the liner and debridement on the 10th day was noted in one knee $(0.6 \%)$.

One patient (1\%) had to undergo treatment due to pulmonary embolism and three other $(3 \%)$ due to deep vein thrombosis. No advancing radiolucency between the bone and implant, implant loosening or displacement were observed at the follow-ups. Considering the aseptic loosening as the final reference point, the survival rate of the whole system was $100 \%$.

A statistically significant difference was detected between the preoperative ranges of flexion of the knees those achieved hyperflexion postoperatively and those did not (Table 2). The statistical evaluation showed a moderate correlation between the pre- and postoperative ranges of motion $(r=0.623$, $\mathrm{p}<0.0001)$. ROC curve analysis confirmed that the knees expected to have a postoperative range of flexion of $130^{\circ}$ or above must have a preoperative range of flexion of $115^{\circ}$ or above (Sensitivity 82\%; Specificity 72\%) (Figure 1). Seventyfour of the 91 knees with a preoperative range of flexion of $115^{\circ}$ or above reached a postoperative range of flexion of $130^{\circ}$ or above, whereas only 16 of the 59 patients with a preoperative flexion of below $115^{\circ}$ reached a postoperative flexion of $130^{\circ}(\mathrm{p}<0.001)$ (Table 3). 


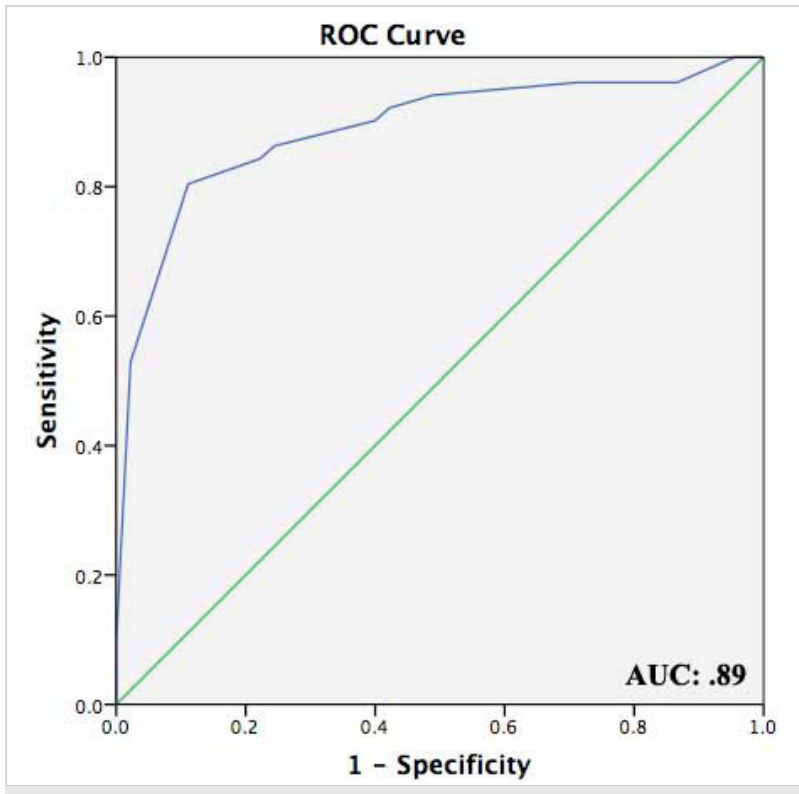

Figure 1 . Receiver operating characteristic (ROC) curve analysis; investigating the required preoperative range of flexion for achieving a high postoperative range of flexion (AUC:0.89)

No significant relationship was found between age and postoperative range of flexion or increase in the range of motion. The preoperative range of flexion was inversely related to the amount of increase in flexion $(\mathrm{r}=(-0.776), \mathrm{p}<0.001)$. No significant correlation was observed between the functional and knee scores and the postoperative flexion results.

\section{Discussion}

The aim of TKA treatment was to obtain a painless knee joint with the adequate and lasting capability of flexion. In our daily lives, we need a flexion range of $60^{\circ}$ for walking on the flat road, $85^{\circ}$ for climbing the stairs, $90^{\circ}-95^{\circ}$ to go down the stairs, and $100^{\circ}-110^{\circ}$ to stand up from the sitting position or to tie shoelaces $(11,12)$. However, considering the social and cultural structures of Eastern populations such as ours, high ranges of flexion of more than $130^{\circ}$ are required for performing numerous moves, such as sitting cross-legged or squatting.

Several total knee prostheses specifically designed for high flexion have been shown to reach $113^{\circ}-139^{\circ}$ of flexion in the short term and these values are significantly higher than those reached by the standard designs $(5,8,13,14)$. In studies investigating the high-flexion inserts such as in ours, the PS designs were mostly investigated $(8,9,15)$. In the study by Laskin et al. (8), the PS-type high-flexion prosthesis was noted to have a mean postoperative flexion of $133^{\circ}$ and this value was significantly higher than that achieved using standard PS design prostheses. However, some authors suggested that no difference was noted between the same high-flex PStype prostheses with postoperative flexion values of $120^{\circ}-133^{\circ}$ and the standard ones $(9,15)$. On the contrary, Crow et al. used a high-flexion CR insert that we used in our series and found a mean flexion of $119^{\circ}$. This value was significantly higher than the mean flexion obtained using a standard insert in their series (10). Our mean flexion of $127^{\circ}$ was higher than the previously reported results of similar design.

In the literature, the age of the patient, tibiofemoral varus-valgus alignment, body mass index, the surgical technique and the prosthetic design were reported to show a relation among the postoperative ranges of flexion (16-18). Our postoperative flexion results were found to correlate with the preoperative flexion values. In addition, there was a negative linear relationship between the increase in the postoperative range of flexion and the preoperative range of flexion.

Knee flexion is an important functional outcome measure in post-TKA evaluations and holds an important place in scoring in several assessments (19). Recently, evaluations filled in by the patients have come to the forefront $(20,21)$. These evaluations inquire the expectations of the patients before surgery, their postoperative thoughts on the success of the surgical outcome, whether the patient is affected by the movement of the joint if any, and whether the patient thinks an additional treatment is necessary. The postoperative range of flexion has been shown to have no relationship of patient satisfaction with some studies (22). However, the increased range of flexion meets the expectations of the patient from the knee, renders the knee functionally capable, and improves the evaluation results of advanced flexion levels $\left(\geq 130^{\circ}\right)(23)$. In another study with similar mean flexion and Knee Society (knee and function) scores, a higher degree of flexion and Knee Society score are directly associated with higher patient satisfaction and their data confirmed that a high postoperative range of knee flexion improves the patientrated outcome (24). In contrast, Thomsen et al. had similar results from high-flexion and standard prosthesis designs in terms of patient satisfaction even high-flex TKA showed increased flexion (25). There was no correlation observed between the range of flexion and the knee and functional scores in our study.

Although the new design features help in increasing flexion, its advantages and usability are debatable. Our femoral component was not a special design; it had a CR insert and required no additional bony cuts. Decreasing the radius of curvature of the posterior femoral condyle and shortening or increasing the thickness of the femoral condyle have been considered while creating some other new designs $(3,13,26)$. It is evident that more bone cuts are required for utilizing these design features. Ranawat asserted that this would complicate the performance of a revision surgery in the future (27). In addition, possible increases in polyethylene wear and patellofemoral complication rates may be another drawback of the attained high flexion. We did not observe any aseptic loosening or advancing radiolucency in our midterm follow-up.

There are some limitations of this study. This was a retrospective study without any control group. Nevertheless, the surgical technique was identical for all knees, which were performed by a single senior surgeon. 


\section{Conclusion}

One of the main deductions of our study was that one can expect a postoperative movement above $130^{\circ}$ in patients who had a preoperative range of flexion of $115^{\circ}$. Using the highflex CR insert is not a sufficient modification for achieving hyperflexion on its own. The preoperative range of flexion is also an important parameter even for such specially designed implants in achieving hyperflexion.

Ethical Committee Approval: Authors declared that the research was conducted according to the principles of the World Medical Association Declaration of Helsinki "Ethical Principles for Medical Research Involving Human Subjects", (amended in October 2013).

Informed Consent: Written informed consent was not received due to the retrospective nature of this study.

Author Contributions: Concept - V.E.Ö., G.D., G.U., İ.R.T.; Design - V.E.Ö.; G.D., G.U., İ.R.T.; Supervision - V.E.Ö., G.D., G.U., İ.R.T; Data Collection and/or Processing - V.E.O., G.D., G.U., İ.R.T.; Analysis and/or Interpretation - V.E.Ö., G.D., İ.R.T.; Literature Review- V.E.Ö.; Writing - V.E.Ö.; Critical Review - G.D., İ.R.T.

Peer-review: Externally peer-reviewed.

Conflict of Interest: The authors have no conflicts of interest to declare.

Financial Disclosure: The authors declared that this study has received no financial support.

Etik Komite Onayı: Yazarlar çalışmanın World Medical Association Declaration of Helsinki "Ethical Principles for Medical Research Involving Human Subjects", (amended in October 2013) prensiplerine uygun olarak yapıldığını beyan etmişlerdir.

Hasta Onamı: Çalışma retrospektif olduğundan dolayı yazılı hasta onamı alınamamıştır.

Yazar Katkıları: Fikir - V.E.Ö., G.D., G.U., İ.R.T.; Tasarım - V.E.Ö., G.D., G.U., İ.R.T.; Denetleme - V.E.Ö., G.D., G.U., İ.R.T.; Veri Toplanması ve/veya İşlemesi - V.E.Ö., G.D., G.U., İ.R.T.; Analiz ve/veya Yorum - V.E.Ö., G.D., İ.R.T.; Literatür Taraması - V.E.Ö.; Yazıyı Yazan - V.E.Ö.; Eleştirel İnceleme - G.D., İ.R.T.

Hakem Değerlendirmesi: Dış bağımsız.

Çıkar Çatışması: Yazarlar çıkar çatışması bildirmemişlerdir.

Finansal Destek: Yazarlar bu çalışma için finansal destek almadıklarını beyan etmişlerdir.

\section{References}

1. Wylde V, Dieppe P, Hewlett S, Learmonth ID. Total knee replacement: Is it really an effective procedure for all? Knee 2007; 14: 417-23. [CrossRef]
2. Robertsson O, Dunbar M, Pehrsson T, Knutson K, Lidgren L. Patient satisfaction after knee arthroplasty: a report on 27,372 knees operated on between 1981 and 1995 in Sweden. Acta Orthop Scand 2000; 71: 262-7. [CrossRef]

3. Dennis DA, Komistek RD, Scuderi GR, Zingde S. Factors affecting flexion after total knee arthroplasty. Clin Orthop Relat Res 2007; 464: 53-60. [CrossRef]

4. Jones CA, Beaupre LA, Johnston DW, Suarez-Almazor ME. Total joint arthroplasties: current concepts of patient outcomes after surgery. Rheum Dis Clin North Am 2007; 33: 71-86. [CrossRef]

5. Bin SI, Nam TS. Early results of high-flex total knee arthroplasty: comparison study at 1 year after surgery. Knee Surg Sports Traumatol Arthrosc 2007; 15: 350-5. [CrossRef]

6. Seon JK, Park SJ, Lee KB, Yoon TR, Kozanek M, Song EK. Range of motion in total knee arthroplasty: a prospective comparison of high-flexion and standard cruciate-retaining designsJ Bone Joint Surg Am 2009; 91: 672-9.

7. Jiang Y, Yao JF, Xiong YM, Ma JB, Kang H, Xu P. No Superiority of High-Flexion vs Standard Total Knee Arthroplasty: An Update Meta-Analysis of Randomized Controlled Trials. J Arthroplasty 2015; 30: 980-6. [CrossRef]

8. Laskin RS. The effect of a high-flex implant on postoperative flexion after primary total knee arthroplasty. Orthopedics 2007; 30: 86-8.

9. McCalden RW, MacDonald SJ, Bourne RB, Marr JT. A randomized controlled trial comparing "high-flex" vs "standard" posterior cruciate substituting polyethylene tibial inserts in total knee arthroplasty. J Arthroplasty 2009; 24: 33-8. [CrossRef]

10. Crow BD, McCauley JC, Ezzet KA. Can high-flexion tibial inserts improve range of motion after posterior cruciate-retaining total knee arthroplasty? Orthopedics 2010; 33: 667. [CrossRef]

11. Laubenthal KN, Smidt GL, Kettelkamp DB. A quantitative analysis of knee motion during activities of daily living. Phys Ther 1972; 52: 34-43. [CrossRef]

12. Kettelkamp DB, Johnson RJ, Smidt GL, Chao EY, Walker M. An electrogoniometric study of knee motion in normal gait. J Bone Joint Surg Am 1970; 52: 775-90. [CrossRef]

13. Huang HT, Su JY, Wang GJ. The early results of high-flex total knee arthroplasty: a minimum of 2 years of follow-up. J Arthroplasty 2005; 20: 674-9. [CrossRef]

14. Weeden SH, Schmidt R. A randomized, prospective study of primary total knee components designed for increased flexion. J Arthroplasty 2007; 22: 349-52. [CrossRef]

15. Malik A, Salas A, Ben Ari J, Ma Y, Gonzalez Della Valle A. Range of motion and function are similar in patients undergoing TKA with posterior stabilised and high-flexion inserts. Int Orthop 2010; 34: 965-72. [CrossRef]

16. Kawamura H, Bourne RB. Factors affecting range of flexion after total knee arthroplasty. J Orthop Sci 2001; 6: 248-52. [CrossRef]

17. Ritter MA, Harty LD, Davis KE, Meding JB, Berend ME. Predicting range of motion after total knee arthroplasty. Clustering, log-linear regression, and regression tree analysis. J Bone Joint Surg Am 2003; 85: 1278-85. [CrossRef]

18. Fuchs MC, Janssen RP. Clinical evaluation of 292 Genesis II posterior stabilized high-flexion total knee arthroplasty: range of motion and predictors. Eur J Orthop Surg Traumatol 2015; 25: 161-6. [CrossRef]

19. Insall JN, Dorr LD, Scott RD, Scott WN. Rationale of the Knee Society clinical rating system. Clin Orthop Relat Res 1989; 248: 13-4. [CrossRef] 
20. Bellamy N, Buchanan WW, Goldsmith CH, Campbell J, Stitt LW. Validation study of WOMAC: a health status instrument for measuring clinically important patient relevant outcomes to antirheumatic drug therapy in patients with osteoarthritis of the hip or knee. J Rheumatol 1988; 15: 1833-40.

21. Dawson J, Fitzpatrick R, Murray D, Carr A. Questionnaire on the perceptions of patients about total knee replacement. J Bone Joint Surg Br 1998; 80: 63-9. [CrossRef]

22. Boese CK, Gallo TJ, Plantikow CJ. Range of motion and patient satisfaction with traditional and high-flexion rotating-platform knees. Lowa Orthop J 2011; 31: 73-7.

23. Devers BN, Conditt MA, Jamieson ML, Driscoll MD, Noble PC, Parsley BS. Does greater knee flexion increase patient function and satisfaction after total knee arthroplasty? J Arthroplasty 2011; 26: 178-86. [CrossRef]
24. Argenson JN, Parratte S, Ashour A, Komistek RD, Scuderi GR. Patient-reported outcome correlates with knee function after a single-design mobile-bearing TKA. Clin Orthop Relat Res 2008; 466: 2669-76. [CrossRef]

25. Thomsen MG, Husted H, Otte KS, Holm G, Troelsen A. Do patients care about higher flexion in total knee arthroplasty? A randomized, controlled, double-blinded trial. BMC Musculoskelet Disord 2013; 14: 127. [CrossRef]

26. Kim YH, Sohn KS, Kim JS. Range of motion of standard and high-flexion posterior stabilized total knee prostheses. A prospective, randomized study. J Bone Joint Surg Am 2005; 87: 1470-5. [CrossRef]

27. Ranawat CS. Design may be counterproductive for optimizing flexion after TKR. Clin Orthop Relat Res 2003; 416: 174-6. [CrossRef] 